Endocrinol. Japon. 1975, 22 (5), 433 437

\title{
5 $\alpha$-Dihydrotestosterone Binding Protein in Rat Ventral Prostate; Purification, Nuclear Incorporation, and Subnuclear Localization
}

\author{
Shogo ICHII
}

\author{
Division of Physiology, Institute of Steroid Research, \\ Tottori University School of Medicine, Yonago 683
}

\begin{abstract}
Synopsis
Treatment of cytosol from the rat ventral prostate with cold acetone $\left(-20^{\circ} \mathrm{C}\right)$ evoked a $8 \sim 10$-fold increase in the binding capacity with $5 \alpha$-dihydrotestosterone (DHT). Starting from the extract of acetone-dried prostate cytosol, some 400 500fold purification of the DHT-binding protein complex was achieved by $\left(\mathrm{NH}_{4}\right)_{2} \mathrm{SO}_{4}$ fractionation, DEAE-cellulose chromatography and gel-filtration with Sephadex G-200. The purified ${ }^{3} \mathrm{H}$-DHT-binding protein complex was incorporated into the nuclei from the ventral prostate in a temperature dependent manner. The similar incorporation was also observed in nuclei from the liver and the kidney. Separation of prostate nuclei into subnuclear fractions revealed that the majority of the incorporated ${ }^{3} \mathrm{H}$ DHT-binding protein complex was located in the fraction of heterochromatin and a relatively small amount of ${ }^{3} \mathrm{H}$-DHT-binding protein complex was observed in the fraction of nucleolei. A slightly different pattern of distribution of ${ }^{3} \mathrm{H}$-DHT-binding protein complex among subnuclear fractions was observed in nuclei from rat liver.
\end{abstract}

The existence of androgen binding protein(s) with specifically high affinity (called receptor) in cytorols of androgen responsive cells is well established and it is generally considered that the steroid-cytosol receptor complex is then transferred to nucleous to play an integral part in the mechanism of androgenic action. Several attempts have been made for purification of this binding protein to gain further insight into the role of steroid-receptor complex in the regulation of metabolic process in target organs (Mainwaring and Irving, 1973; Katsumata and Goldman, 1974; Fang and Liao, 1971). However, biochemical sequences which take place in the cells after incorporation of the steroid-receptor complex into nuclei have not been fully elucidated.

In the present experiment, some over-all

Received for publication May 22, 1975.
$400 \sim 500-$ fold purification of $5 \alpha$-dihydrotestosterone (DHT) binding protein from acetone-dried cytosol of the rat ventral prostate was achieved by relatively simple procedures. Intranuclear localization of the purified DHT-binding protein complex was also examined by incubating the purified nuclei with the complex.

\section{Materials and Methods}

\section{Animals and tissue preparations}

Adult male Wistar rats weighing $300 \sim 350 \mathrm{~g}$ were used throughout the experiment. Animals were exsanguinated and removed ventral lobes of the prostate were homogenized either in a medium containing $50 \mathrm{mM}$ Tris- $\mathrm{HCl}$ (pH 7.5), $250 \mathrm{mM}$ sucrose, $25 \mathrm{mM}$ $\mathrm{KCl}, 3 \mathrm{mM} \mathrm{MgCl}_{2}, 1 \mathrm{mM}$ 2-mercaptoethanol and 1 mM EDTA (buffer A) or in another medium which consisted of $10 \mathrm{mM}$ Tris- $\mathrm{HCl}(\mathrm{pH} 7.5), 0.5 \mathrm{mM}$ EDTA and $1 \mathrm{mM}$ 2-mercaptoethanol (buffer B). Cytosol was obtained after centrifuging the homogenate made 
in buffer $\mathrm{B}$ at $150,000 \times \mathrm{g}$ for $60 \mathrm{~min}$ and purified nuclear fraction was prepared from buffer A homogenate by the method of discontinuous sucrose gradient centrifugation described by Blobel and Potter (1966). Separation of nuclei into subnuclear fractions was performed according to the method of Tata and Baker (1974) with minor modifications, in which $1.17 \mathrm{M}$ sucrose layer was omitted from the discontinuous gradient.

Preparation of acetone-dried cytosol from rat ventral prostate

Cytosol from the rat ventral prostate prepared as described above was slowly poured into 9 volumes of chilled acetone $\left(-20^{\circ} \mathrm{C}\right)$ with vigorous stirring. The precipitate formed was quickly separated by centrifugation and washed with ethylether $\left(-20^{\circ} \mathrm{C}\right)$ then dried in vaccuo. The dried power thus prepared can be stored at $-20^{\circ} \mathrm{C}$ at least for 6 months without any appreciable loss of binding activity. The powder was suspended in buffer B, homogenized briefly and centrifuged at $15,000 \times \mathrm{g}$ for $30 \mathrm{~min}$. The resultant supernatant was used as the source of the binding protein.

\section{Determination of binding capacity}

Incubation for determination of the binding capacity was carried out in a final volume of $0.5 \mathrm{ml}$ which contained $10 \mathrm{mM}$ Tris- $\mathrm{HCl}(\mathrm{pH} 7.5), 0.5 \mathrm{mM}$ EDTA, $1 \mathrm{mM}$ 2-mercaptoethanol and $2 \mathrm{nM}{ }^{3} \mathrm{H}-\mathrm{DHT}$ $(20,000 \mathrm{cpm}$, The Radiochemical Centre, Amersham, England, specific activity, $175 \mathrm{Ci} / \mathrm{mmole}$ ) at $0^{\circ} \mathrm{C}$ for 3 hrs. Separation of the free-from-bound steroid was performed by dextran coated charcoal.

\section{Other methods}

Protein and DNA were determined by the methods of Lowry et al. (1951) and Burton (1956), respectively. Radioactivity of the bound steroid was determined after extraction of steroid with $3 \mathrm{ml}$ of ethanol in a Tri-Carb liquid scintillation spectrometer with automatic external standardization for quenching correction.

\section{Results and Discussion}

As seen in Fig. 1, treatment of cytosol from the rat ventral prostate with cold acetone evoked a $8 \sim 10$-fold increase in the binding capacity with ${ }^{3} \mathrm{H}-\mathrm{DHT}$, when compared on the weight basis of protein. This might be attributable, at least in part, to elimination of endogenous steroids and other substances of lipid nature which might inter- fere the binding of ${ }^{3} \mathrm{H}-\mathrm{DHT}$ to protein. Aliquots of the acetone powder extract were incubated in the presence of various concentrations of ${ }^{3} \mathrm{H}-\mathrm{DHT}$ (ranging from 0.05 to 10 $\mathrm{nM}$ ) at $0^{\circ} \mathrm{C}$ for $3 \mathrm{hrs}$ and $\mathrm{Ka}$ was calculated as $3.7 \times 10^{10} \mathrm{M}^{-1}$. Starting from the extract of acetone powder, further purification of ${ }^{3} \mathrm{H}-\mathrm{DHT}$-binding protein was conducted using relately simple procedures (Table 1.). $180 \mathrm{mg}$ of the acetone-dried powder were extracted with $20 \mathrm{ml}$ of buffer $\mathrm{B}$ and incubated at $0^{\circ} \mathrm{C}$ for $6 \mathrm{hrs}$ in the presence of

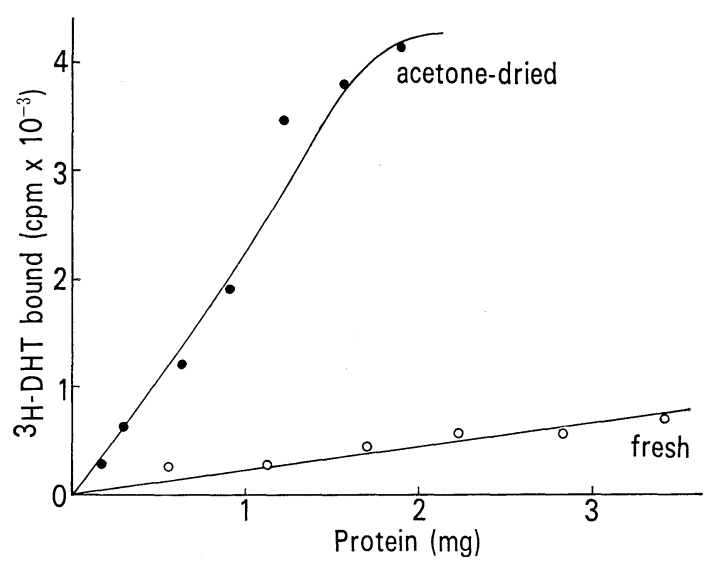

Fig. 1. Binding of ${ }^{3} \mathrm{H}-\mathrm{DHT}$ to proteins of fresh cytosol and acetone-dried cytosol from rat ventral prostate. Incubations were carried out in $0.5 \mathrm{ml}$ of buffer $\mathrm{B}$ which contained $2 \mathrm{nM}$ of ${ }^{3} \mathrm{H}-\mathrm{DHT}$ $(20,000 \mathrm{cpm})$ at $0^{\circ} \mathrm{C}$ for $3 \mathrm{hr}$. For other details of the experimental conditions, see the text.

Table 1. Purification of DHT-binding protein from acetone-dried cytosol of ventral prostate.

\begin{tabular}{lcc}
\hline \multicolumn{1}{c}{ Fractions } & $\begin{array}{c}\text { Recovery of } \\
\text { protein* }\end{array}$ & $\begin{array}{c}\text { Binding activity } \\
(\mathrm{dpm} / \mu \text { g protein })\end{array}$ \\
\hline $\begin{array}{l}\text { Acetone powder ex- } \\
\text { tract }\end{array}$ & 100 & 5.6 \\
$\begin{array}{l}45-60 \% \quad\left(\mathrm{NH}_{4}\right)_{2} \mathrm{SO}_{4} \\
\text { fraction }\end{array}$ & 18 & 55 \\
$\begin{array}{l}\text { DEAE } 300 \mathrm{mM} \mathrm{KCl} \\
\text { eluate }\end{array}$ & 2.5 & 247 \\
$\begin{array}{l}\text { Sephadex G-200 frac- } \\
\text { tion }\end{array}$ & 1.6 & 320 \\
\hline
\end{tabular}

$180 \mathrm{mg}$ acetone-dried cytosol were used as the starting material.

* Amount of protein in the buffer extract of acetonedried powder was taken as 100 . 
$7 \mu \mathrm{Ci}$ of ${ }^{3} \mathrm{H}-\mathrm{DHT}$. After removing unbound steroid with dextran coated charcoal, stepwise fractionation with $\left(\mathrm{NH}_{4}\right)_{2} \mathrm{SO}_{4}(0-30$, $30-45,45-60,60-80 \%$ saturation) of the incubated extract was then performed. The radioactivity was concentrated in $45-60 \%$ fraction and the specific radioactivity $(\mathrm{cpm} /$ $\mu \mathrm{g}$ protein) in other 3 fractions was less than $1 / 10$ of that of the $45-60 \%$ fraction. The $45-60 \%$ fraction was desalted through Sephadex G-25 column $(12 \times 400 \mathrm{~mm})$ and then applied to DEAE column $(10 \mathrm{~mm} \times$ $120 \mathrm{~mm}$ ) which had previously been equilibrated with buffer B. The column was eluted stepwise with buffer B which contained an increasing amount of $\mathrm{KCl}(0-500 \mathrm{mM})$. Most of the radioactivity appeared after elution of the column with buffer B containing $300 \mathrm{mM} \mathrm{KCl}$. The eluate of $300 \mathrm{m.M}$ $\mathrm{KCl}$ was subjected to the gel-filtration with Sephadex G-200 column $(8 \mathrm{~mm} \times 780 \mathrm{~mm})$ which had been swollen in buffer $B$. The column was eluted with buffer $B$ and the radioactivity appeared between $30 \mathrm{~m} l$ and $36 \mathrm{ml}$ as a single symmetrical peak. Overall purification of some 60-fold from the extract of acetone-dried power was obtained. $\mathrm{Ka}$ tsumata and Goldman (1974) separated four DHT-binding proteins using microelectrofocusing procedure from nuclei and cytosol of the rat ventral prostate. In the present study only one DHT-binding component was detected throughout the purification procedure. The purified ${ }^{3} \mathrm{H}-\mathrm{DHT}$-binding protein complex was relatively stable. It can be stored at $0^{\circ} \mathrm{C}$ with half-life of 4 days. When stored at $-20^{\circ} \mathrm{C}$ in a frozen state, liberation of the radioactivity was more rapid (Fig. 2). The purified ${ }^{3} \mathrm{H}-\mathrm{DHT}-$ binding protein complex was incorporated into purified nuclei from the ventral prostate, in a temperature dependent manner (Table 2.). Purified nuclei were suspended in buffer A containing $0.5 \%$ bovine serum albumin (BSA) and incubated with the purified ${ }^{3} \mathrm{H}-\mathrm{DHT}$-binding protein complex under the incubation conditions indicated

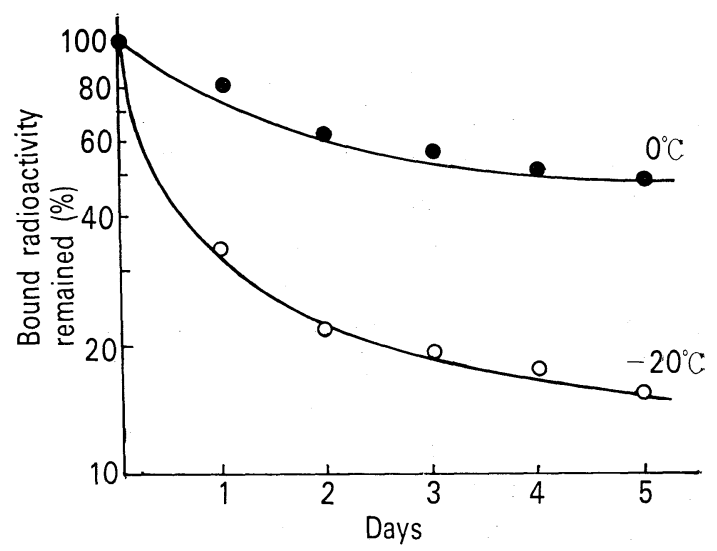

Fig. 2. Liberation of the radioactivity from purified ${ }^{3} \mathrm{H}$-DHT-binding protein complex during storage either at $0^{\circ} \mathrm{C}$ or $-20^{\circ} \mathrm{C}$. Bound radioactivity remained was determined after absorption of the free radioactivity with dextran coated charcoal. In the case of $-20^{\circ} \mathrm{C}$ storage, samples were thawed in ice-cold water, then free steroid was absorbed.

Table 2. Incorporation of ${ }^{3} \mathrm{H}-\mathrm{DHT}$-binding protein complex into purified nuclear fraction isotated from the ventral prostate, the liver and the kidney of rats.

\begin{tabular}{lcc}
\hline $\begin{array}{c}\text { Source of } \\
\text { nuclei }\end{array}$ & $\begin{array}{c}\text { Incubation } \\
\text { conditions }\end{array}$ & $\begin{array}{c}\text { Incorporation of } \\
\text { radioactivity } \\
\text { (dpm/ } / \mu \mathrm{g} \mathrm{DNA})\end{array}$ \\
\hline Prostate & $0^{\circ} \mathrm{C}$ for $2 \mathrm{hrs}$ & 14.3 \\
& $20^{\circ} \mathrm{C}$ for $2 \mathrm{hrs}$ & 25.3 \\
Liver & $37^{\circ} \mathrm{C}$ for $20 \mathrm{~min}$ & 30.2 \\
& $0^{\circ} \mathrm{C}$ for $2 \mathrm{hrs}$ & 5.9 \\
Kidney & $20^{\circ} \mathrm{C}$ for $2 \mathrm{hrs}$ & 14.6 \\
& $37^{\circ} \mathrm{C}$ for $20 \mathrm{~min}$ & 19.8 \\
& $0^{\circ} \mathrm{C}$ for $2 \mathrm{hrs}$ & 6.4 \\
& $20^{\circ} \mathrm{C}$ for $2 \mathrm{hrs}$ & 15.5 \\
& $37^{\circ} \mathrm{C}$ for $20 \mathrm{~min}$ & 21.7 \\
\hline
\end{tabular}

Nuclei were separated from $2 \mathrm{~g}$ of prostate (from 7 rats), $3 \mathrm{~g}$ of liver and from $3.5 \mathrm{~g}$ of kidney cortex, respectively. Each nuclear fraction was suspended in $1 \mathrm{ml}$ of buffer A and incubated in the presence of $420,000 \mathrm{dpm}\left(0.55 \mathrm{mg}\right.$ as protein) of purified ${ }^{3} \mathrm{H}-$ DHT-binding protein complex. 
in the legend to Table 2. After incubation, $5 \mathrm{ml}$ ice-cold buffer $\mathrm{A}$ was added and the nuclei were recovered by centrifugation. The nuclei were washed 3 times with buffer A and finally suspended in $2 \mathrm{~m} l$ of the same medium. An aliquot of the suspension was taken for determination of DNA and another was used for determination of the radioactivity. As seen in Table 2, nuclei took up more radioactivity when incubated at $37^{\circ} \mathrm{C}$. Activation of the steroid-receptor complex by rasing the temperature has been reported (Baxter and Tomkins, 1971). The similar incorportion of the complex was also observed when comparable amounts of purified nuclei from the liver or the kidney cortex were incubated under the same incubation conditions, although the rate of uptake was significantly lower than that observed in nuclei from the ventral prostate. It has been observed by Buller et al. (1975) that a significant amount of ${ }^{3} \mathrm{H}$-progesteronechick oviduct receptor complex was incorporated into purified nuclei from the heart, the liver, the erythrocyte and the colon. From these observations the nuclear specificity for steroid hormone-cytosol receptor complex does not seem to be very strict. On the other hand, cytosol seems to have a strict specificity for the steroid, since extracts of acetone-dried powder either from the liver or from the kidney cytosol did not bind significant amount of ${ }^{3} \mathrm{H}-\mathrm{DHT}$.

The nuclei incubated with purified ${ }^{3} \mathrm{H}-$ DHT binding protein were recovered by centrifugation and washed 3 times with buffer $A$, and then separated into subnuclear fractions by the method of Tata and Baker (1974), followed by the determination of the radioactivity in each fraction. Three experiments were performed independently and almost identical results were obtained. Results of a typical experiment were tabulated in Table 3. In the present experiment, each fraction was not examined electronmicroscopically, therefore nomenculature of each fraction is rather tentative but determination of DNA, protein and organic sol-

Table 3. Distribution of the radioactivity of purified ${ }^{3} \mathrm{H}$-DHT-binding protein complex among the subnuclear fractions after incubation with the nuclei in vitro.

\begin{tabular}{llccc}
\hline \hline $\begin{array}{l}\text { Source of } \\
\text { nuclei }\end{array}$ & \multicolumn{1}{c}{ Fractions } & $\begin{array}{c}\text { Total } \\
\text { radioactivity } \\
(\mathrm{dpm})\end{array}$ & \multicolumn{2}{c}{ Binding activity } \\
\cline { 5 - 5 } Prostate & & & $\mathrm{dpm} / \mu \mathrm{g}$ protein & $\mathrm{dpm} / \mu \mathrm{g}$ DNA \\
& Nucleoplasm & 15135 & 50.5 & not determined \\
& Euchromatin & 5540 & 17.9 & 36.6 \\
& Nuclear membrane & 8740 & 11.5 & 23.1 \\
& Nucleolei & 3985 & 10.4 & 24.2 \\
& Fraction 6 & 1860 & 5.7 & 10.8 \\
& Heterochromatin & 33185 & 27.2 & 51.7 \\
& & & & \\
& Nucleoplasm & 21016 & 66.0 & not determined \\
& Euchromatin & 4455 & 12.4 & 27.3 \\
& Nculear membrane & 10816 & 5.8 & 10.9 \\
& Nucleolei & 4117 & 4.3 & 9.4 \\
& Fraction 6 & 2040 & 2.8 & 5.2 \\
& Heterochromatin & 12090 & 10.9 & 19.7 \\
\hline
\end{tabular}

Nuclei from $3.2 \mathrm{~g}$ of prostate (from $10 \mathrm{rats}$ ) and from $3.5 \mathrm{~g}$ of liver were suspended in buffer A containing $0.5 \% \mathrm{BSA}$ and incubated in the presence of $1,400,000 \mathrm{dpm}\left(0.43 \mathrm{mg}\right.$ as protein) of purified ${ }^{3} \mathrm{H}-\mathrm{DHT}$ binding protein complex for $30 \mathrm{~min}$ at $30^{\circ} \mathrm{C}$. After washings and sonication, each subnuclear fraction was separated by discontinuous sucrose gradient centrifugation. Nomenculature of the subnuclear fractions was followed by the description of Tata \& Baker (1974). Fraction 6 was probably consisted mostly of the inner membrane. For details, see the text. 
vent extractable $\mathbf{P}$ in each fraction revealed that the fraction obtained in the present study was very similar to those reported by Tata and Baker (1974) in such respects.

Most of the radioactivity in the nucleoplasm was found to be charcoal absorbable, so it might be concluded that the radioactivity in this fraction was the one liberated during the fractionation procedures. In the nuclei of the ventral prostate a majority of the incorporated radioactivity was located in the heterochromatin and the radioactivity in the fraction of nucleolei was much less than that found in the heterochromatin fraction. In the nuclei of liver, relatively large amount of the radioactivity was observed in the heterochromatin and the nuclear membrane. When the radioactivity of fractions was compared on the weight basis of protein or DNA, except the nucleoplasm which seems not to be in bound form, the highest incorporation was observed in the euchromatin fraction in contrast to the heterochromatin in the prostate nuclei. Relatively low incorporation into the liver nucleolei was also noticed.

Physiological interpretations of the results obtained in this experiment seem to be very difficult since the distribution of the radioactivity in the nuclei could be modified during the nuclear disruption and separatuon procedure. A large amount of the radioactivity was observed in the chromatin frac- tions of both ventral prostate and liver but it is not clear whether this represents a real intranuclear localization ${ }^{3} \mathrm{H}$-DHT-binding protein complex or an artifact induced by the nuclear disruption since high affinity of DNA with steroid-receptor complex was reported by Irving and Mainwaring (1974).

\section{References}

Baxter, J. D. and G. M. Tomkins (1971). Proc. Nat. Acad. Sc. 68, 932.

Blobel, G. and V. R. Potter (1966). Science 154, 1662.

Buller, R. E., D. O. Toft, W. T. Schrader and B. W. O'Malley (1975). J. Biol. Chem. $250,801$.

Burton, K. (1956). Biochem. J. 62, 315.

Fang, S. and S. Liao (1971). J. Biol. Chem. 246, 76.

Irving, R. and W. I. P. Mainwaring (1974). J. Steroid Biochem. 5, 711.

Katsumata, M. and A. S. Goldman (1974). Biochim. Biophys. Acta 359, 112.

Lowry, O. H., N. J. Rosenbrough, A. L. Farr and R. J. Randall (1951). J. Biol. Chem. 193, 265.

Mainwaring, W. I. P. and R. Irving (1973). Biochem. J. 134, 113.

Tata, J. R. and B. Baker (1974). Exp. Cell Res. 83, 111. 